\title{
The Impact of Teacher Education and English Language Education in Fostering Global Citizenship Education: A review of literature
}

\author{
Kumari Ekanayake ${ }^{1}$, Ali Khatibi ${ }^{2}$, Dr. S.M. Ferdous Azam ${ }^{3}$ \\ Research Scholar ${ }^{1}$, Professor $^{2}$, Doctor ${ }^{3}$ \\ Faculty of Management \\ Management and Science University (MSU) \\ Malaysia
}

\begin{abstract}
The notion of Global Citizenship Education (GCE) has become a buzzword of educational discourses and policies of the contemporary world in which it aims to create knowledgeable, empathetic and skillful personnel with a view to ensure peaceful, tolerant, inclusive and sustainable global society. This renewed and transformative educational approach is a framing paradigm that encapsulates the role of education in forming competent citizens who actively and responsibly participate with critical awareness and understanding in this interconnected and interdependent world with its accelerating challenges and opportunities by disregarding any kind of manmade differences. Since teachers are the key to deliver such an education, this scenario demands teachers to be professionals possessing strong subject and pedagogical knowledge with appropriate managerial skills, readily adopt technologies and stay focused on the diverse and sensitive needs of their students. Therefore, building teachers' capacity through teacher education should be a compulsive continuum. Moreover, with this approach, it is imperative to participate and collaboratively work as members of a global society. Thus, it is feasible to reach the intended goals through the English language as the linking language of the global community. Thereby, fostering GCE, with complementary effects between Teacher education (TE) and English Language Education (ELE) will be revealed by this study based on the literature review.
\end{abstract}

Keywords: Global Citizenship Education, Teacher Education, English Language Education, Transformative education.

\section{INTRODUCTION}

Global Citizenship Education, (GCE) that assures transformative aspect of personal as well as social life of the current world has taken key role of education. This important approach to education has not only given prominence in the agendas of educational scholars and policy makers but also indispensable subject in educational research. In spite of its prominence, because of its multidimensional and complex nature, GCE lacks clear and definite definition. However, the UNESCO amongst other organizations, as the lead agency indicates, align with the rapid changes and challenges of this globalized world and going away from national borders as members of the planet earth, GCE, through its transformative approach, aims to cope up with these challenges and direct the world towards sustainable development.

In regard to Teacher Education (TE), a body of literature indicates teacher quality is the single most important determiner of students' learning (Brunc and Luque, 2015) cited by [1] .The impact of teachers, is the key of implementing reforms and changes in education and also navigating them into success .Further, there is a strong correlation between individual teacher's personal learning with students' achievement. Therefore, not only through pre-service learning, enhancing their knowledge, pedagogical skills and motivation from in-service learning as well as well-planned continuous professional learning programs are very beneficial to students' achievement [2]

Correspondingly, implementing GCE work demands substantial efforts because this element cope with challenging issues. Hence, strengthening the teachers capacity and equipping them with due pedagogical skills and exposing them into different cultural and international experience to fast tract their capability while giving them administrative and leadership skills are essential [3]. As (Akkari and Maleq,2019) [4] point out need to foster GCE is stronger than ever, it can only be accomplished by effective and 
flexible in service TE and delivering informally with close collaboration amongst teachers, students and other stake holders. In this perspective, since teachers can make important contribution particularly, in responding and developing the ideals of GCE; ecological, social, cultural and political changes in the world. Moreover, in their initial and continuous professional development programs, GCE should be promoted [5]. They further state, even if teacher education has critical role, in most cases, provision of such courses for them, perceive as something optional and extra. As a result, in spite of most welcomed, learner centered, participatory and transformative pedagogical practices, many parts of the world, transmission approach still dominates. In contrast, align with students' desired and sophisticated form of learning, education in the 21 st century is becoming increasingly complex and skill based. Thus, teachers should be provided with effective professional development programmes to teach these skills [6]. Confirming, it Garcia and Weiss, (2019) [7] also indicate, particularly with GCE, it is imperative to provide early career and continuous professional trainings enabling teachers to gain new knowledge, skills and update their technological skills keeping with new demands of students as well as to elevate teaching profession.

Consequently, with GCE, teachers' role is not restricted to transferring knowledge, but to create conducive learning environment for students to be productive, ethical, moral and responsible citizens of this past paced and inter connected world. To do so, teachers should have strong subject and pedagogic knowledge with effective classroom management skills, adapt new technologies and be sensitive to diverse needs of students. Therefore, building capacity of teachers to meet these challenges of GCE is a top priority [8].

With reference to both kinds of language teaching; foreign language teaching or second language teaching, the key purposes are the development of individual and evolution of societies. To achieve this central goal, despite the fact that language education can make a specific contribution, most of the countries attempt to learn citizenship education through whole school curricula approach in the current world [9]. As Porto (2019) further points out, the complimentary nature of foreign language learning (EFL) with its emphasis on intercultural communicative competence coincide very well with functional as well as instrumental purposes of both these phenomena. To accomplish this duel approached teaching and learning process with its theoretical, methodological and innovative teaching background, should be practiced with meaningful content. In light of this, both these phenomena interested in developing learners' competences, knowledge and attitudinal behavior in collaboration. Particularly, prime aim of English Language Education (ELE) is developing intercultural communicative skill. This in turn, key aspect of GCE too.

Not only facilitating intercultural competence, every space in English language classroom with its meaningful and wider context, seems to be provided an ideal space to develop global citizenship [10]. As he further elaborates educating people as citizens of the world has become necessitated more than ever before. In light of this, to build up active global citizenship, English should be articulated so do with keeping intercultural relationships; key concept of GCE .Therefore, development of GCE ideals through ELE is feasible by taking central and innovative pedagogical role .Thus, it is not necessary to deliver mainly through social studies . Moreover, as specified by (Byram (2019) et al: [11] the impact of globalization has created profound changes such as ,digital revolution, multicultural and multilingual communication and also challenges like, mass migration, global terrorism, refugee crisis, global epidemics and pandemics together with natural or manmade catastrophes in the contemporary world we live in. This trend has massively changed citizenship education which had been limited to national identity. These challenges and opportunities have focused the shift in creating diplomatic, intercultural and interactive relationships. Language teachers together with citizenship educators can foster these new perspectives of intercultural citizenship dimension of language education created by globalization through effective and innovative teacher education.

\section{OBJECTIVES OF THE STUDY}

This study which is based on review of literature, on the impact Teacher Education and English Language Education in fostering Global Citizenship Education, comprised of the following mentioned objectives.

1. To investigate various research work that has been done in the study area.

2. To examine the relationship between study variables

\section{Methodology and Study Model}

This descriptive study used only secondary data mostly derived from various research journals in related field. 


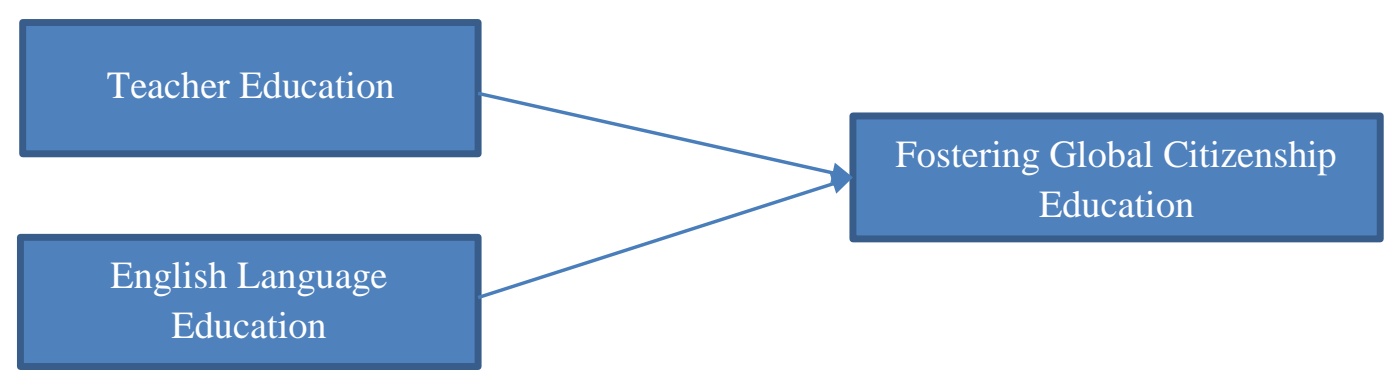

Figure 3.1: Study Model

\section{FOSTERING GLOBAL CITIZENSHIP EDUCATION (GCE)}

GCE is an urgently need key of educational approaches which empowers learners to engage and assure active role both locally and globally in them as proactive contributors to a more just peaceful, tolerant, inclusive, secure and sustainable world [12] . As such, the learning outcomes are covered with three domains namely; cognitive, socioemotional and behavioural domain. All these 3 domains together create well balanced learning experiences to form well rounded personalities [12] Specified by body of literature the discourse of GCE is imperative to gain knowledge, skills, competence and empathetic attitude to cope up challenges and ability to take insightful actions for the wellbeing of one's self and the entire mankind of global society [4, 13-17]. Having broader views [13] conceptualizes GCE framework as much looking forward educational theory based on values of mutuality and reciprocity, despite its intrinsic but resolvable contradictions. Further, it encourages the way of acting in a community centric, ecologically balanced and culturally sensitive society in the ongoing construction of just and peaceful world. In fact, GCE is a form of intervention in searching for a theory and agency of implementation because the world is becoming increasingly interdependent and diverse and its borders more porous. Concurrently, at the level of classroom and curriculum setting excellent educators are engaged in GCE.

In contrast, resistance to GCE would absolutely intensify social instability, tensions and conflicts and also the opportunity of developing the world collaboratively. Therefore, GCE is essential than ever today since it makes sense of how global and local affairs are interrelated, interdependent and also to recognize opportunities, to possess necessary skills to act and use the opportunities they encounter [13] In that, GCE enriches and enable people to lead a successful life in this world that is being interconnected at an accelerating speed. In consequence, GCE as key form of learning in the citizens' of this globalized world, has become prompt concept in education discourses and policies around the world [18].

However, implementation of GCE work required sustainable efforts. That being so, to accomplish this massive task, building teacher competence through effective and strategic teacher education programs is a critical requirement [3].

\section{GCE IN TEACHER EDUCATION (TE)}

To actualize the intended goals of GCE, preparation of teachers and facilitating them duly are critical whereas, it is a challenging enterprise [19].As Kopish and Marques (2019) further emphasize, it is imperative to upgrade teacher education programs corresponding with rapid changes of this increasingly interconnected world. Particularly, through TE, if they can enhance teachers' Collaborative Online Interactive Learning (COIL), the changes created by globalization can be complimentary and in turn transformative learning in connection with GCE can also be ensured.

Accordingly to Akkari and Maleq (2019) [4], even an individual teacher can make a big impact in the classroom. Hence, fostering teacher competence and building their confidence through systematic professional development programmes is critical [6].However, as revealed by Banele's (2019) study, in contrast to what the teachers are supposed to do, they continue to follow traditional pedagogies comfortably mainly due to lack of effective TE, infrastructure facilities, follow up work and discriminatory nature of some TE . Nonetheless, a substantial amount of literature acknowledges his findings [20], [21] and [8]. In essence, in terms of GCE, teachers are required to deepen their knowledge aligned with new demands and changes in curricula because, effective teaching need practice and 
teachers must be nurtured through high quality continuous learning programs to acquire such knowledge, skills and attitude, to do their job well [8]. In a nutshell, before delivering GCE skills to their students' teachers, themselves should possess these skills to ensure them in their students.

However (UNESCO, 2018) [8] indicates lack of teacher capacity as one of the key barriers to GCE. Particularly, in ensuring quality education, teachers face lot of pressure. Teachers often find it difficult to make room for GCE, for instance, to imbed GCE contents into their lessons, and make connections with GCE ideals in the existing curricula. Therefore, they too strongly urge capacity building initiatives for teachers in regard to GCE [3]. Nonetheless, as it is suggested by UNESCO (2018) teachers as well as teacher educators should be provided necessary curricula resources and materials covering broad spectrum of issues, pedagogies and subjects to practice GCE ideals with their teaching. Further, to ensure sustainable TE it should start from pre-service TE with a strong foundation and continue through inservice TE throughout their career.

Therefore, in this study, TE takes multi-dimensional approach focusing all kinds of teacher education starting from pre service TE, teacher induction program, in service teacher education and continues professional development programs as separate entities of continuum TE [1].

\section{GCE IN ENGLISH LANGUAGE EDUCATION (ELE)}

The essential requirement of fostering GCE in order to sustainably practice its intended ideals, for the wellbeing of the mankind has become more important than ever in the current world. In consequence, ultimate goal of education is not restricted to mastering subject knowledge, receiving good results at high stake exams and getting a good occupation but it is also about equipping the students for global citizenship to make the world a better place. Favourably, in this scenario, since ELE teaching by its nature international it can be enriched by reference to GCE [11].As points out by body of empirical studies the prominent method of incorporating and delivering GCE elements are transversely across the curricula $[12,15,20,22]$.

However, if we are to meet the requirements of $21^{\text {st }}$ century, all educators, including English as a Foreign Language (EFL) should educate students for more peaceful and sustainable world. Therefore, not only equipping learners with the target language but also equipping them with the knowledge of the existing global issues and helping them to develop required skills, values and attitude for them to become responsible and competent inhabitants of the current world [11]. In the event of globalization, digitalized communicative competence require more linguistic knowledge and skills than theories. For instance, intercultural communication is essential between self and others to engage in effective and appropriate communication [11]. That is by having communicative competence in English as the language of global communication. They emphasize the way English has become lingua franca with the advancement of technology. Particularly, internet and social networks. Thus, teaching English and mastering this language inevitably contributes to education as global citizens.

On the positive side in the field of English Language Education, GCE has a natural place [16]. Having similar views, Diaz (2017) [10] indicates even though, English Language teaching (ELT) and GCE has not been conventional point of concern the complimentary nature of this dual approach which provides meaningful and wider contexts is an ideal space to develop global citizenship. As he further elaborates this joint approach facilitates to maintain intercultural competence and relationships amongst the citizens of multicultural societies. In doing so, it truly facilitates teachers and students to be more participative while preserving sustained relationships. It in turn one of the ultimate goals of EFL too.

Moreover, the key objectives; building up empathetic and active citizenship while attempting to solve dynamic issues of the world and engage in peace building efforts of GCE are visible and feasible in EFL classrooms too. Such similar themes and pedagogies of GCE and EFL set the background to this coherent approach .Subsequently, the aims of language teaching, whether it is EFL or ESL are coincide with the aims of GC [10] . Meanwhile, as highlighted by Oxfam (2015) [23] this joint approach encourage teachers and students to become more participatory and actually engage in GCE work. The cohesive nature of both these approaches are further conspicuous as it is highlighted by [9] For instance, in the context of EFL intercultural communicative competence is given a prominent place .In that innovative cross cultural cooperation through meaningful and contextual contents should be provided. Correspondently, intercultural competence, cooperation, critical thinking are the key elements of GCE too. 
In this light, to reach to the intended goals of both these discourses, competence in English is essential to enhance intercultural communication and interaction. This intercultural citizenship dimension which is an innovative development in the field of language learning has the capacity to enrich prominent ideals of GCE too. In this way language teachers and citizenship educators have much to learn from each other. However, in spite of this reciprocal nature educating for global citizenship remains as a neglected role of EFL pedagogy [11].

\section{THEORETICAL PERSPECTIVES OF THE STUDY}

Theoretical perspectives are the foundation on which the entire research project is based .It is comprised of elaborated network of associations amongst the variables deemed relevant to the problem situation of the study [24] p.80. Accordingly, theatrical framework represents logical connections amongst the study variables while elaborating the theatrical base underlie these connections. Consequently, the following table no: 1 and 2 summarize the theoretical references of GCE and ELE respectively.

\subsection{Theoretical Perspectives of GCE}

Considering the reviews of literature on theoretical foundation of GCE particularly, in terms of teacher education, it has been noted that the epistemological standpoint of this study is appeared to center around amalgamation of Transformative Theory, Active Learning Theory (Constructivism) and Reasoned Action Theory.

\subsection{Transformative Theory}

Transformative Learning theory developed by Jack Mezirow in 1970 claims that every individual has his or her own points of view of the world. Mezirow (1997) [25] opines, that these world views formed unconsciously, based on his or her upbringing, life experience, culture and education. He further points out, our habits and minds influence our points of view, thoughts and feelings. To change our points of view it is necessary to discuss, interpret, analyse, and reflect and giving feedback appropriately. Hence, transformative learning takes place through discussion, arguments, critical thinking, and self-reflection and project work. Nevertheless, one's own habits are based on these views [26]. As they further comment, Transformative Learning is an independent thought in which we assess validity of our learning that enable us to apply what we learn in an unexpected situations. Therein, this learning is feasible, if the students are adequately motivated to critically assess, challenge and change their assumptions in different situations. Thus, Transformative Learning paves the way for them to be lifelong learners in this fast paced world.

Accordingly, this theory is basically focuses upon essential nature of change in learners' preconceptions and world views on learning. On the other hand, the greatest challenge in the education process is engaging learner not in informatively but trans formatively [27]. As [27] further points out it is a complex process, affected by the nature of the learner, learning environment and the content and also the context of the society. Since this process does not have a cohesive model, he suggests to have interactive and integrated model to better yield the objectives of this perspective. In this fashion, this theory strives to know how learners construct, validate and reformulate their learning experience [28]. As they point out with this self-directed learning process, it is necessary to provide the learners a safe learning environment with stimulating and challenging learning opportunities for them to develop and transform. On account of that, with GCE it is necessary to deal with the issues in both, local and global level with participatory strategies and methods. The most suitable pedagogy in this discourse is transformative approach in which it engages the learner beyond the classrooms. Therefore, transformative teaching and learning make changes possible both at individual, community or institutional levels.

In this respect, this theory employs holistic approach in which it necessarily employs learner centered pedagogies with rational, cognitive, creative and intuitive transformation in learners' personality [27].Moreover, it involves network of connections, understandings, awareness and consciousness amongst ourselves, other human beings and with natural world. Through such connections it tends to create a deep structural shift of consciousness that is dramatically and irreversibly alters one way of being in the world by inter locking structure of class, race, gender etc. [29].Therefore, in pursuing such transformation the learners will have to assist with adequate opportunities, for them to reflect on critical thinking and participate in social action.

\subsection{Active Learning Theory: (Constructivism)}


Constructivism is one of the most influential theory which is mostly associated with Jean Piaget. This theory of knowledge has a wide ranging impact on learning and teaching. Particularly the concept of "Student Centered Education" is prominent. As constructivists believe learning occurs in a contextual setting [30].

According to this theory both the students and the teachers blend in conversation and work in connection with societal issues at local and global level. Therefore, this too is an action oriented, rights based educational approach in which the students become interactive and engage in social process [31].To have broader look towards constructivism as indicated by him, it encourages students to constantly involve in discussions, discover by themselves through experiences while tapping their innate curiosity about the world and how things work .In this process the teacher acts as a facilitator and promotes autonomy of the students and stimulates them for active learning.

\subsection{Reasoned Action Theory}

According to the theory of Reasoned Action developed by Fishbein and Ajzen (1975) as cited by [32] an individual's behaviour arises from inter related combination of how one thinks, feels about an idea which then promotes the intention to act that results in actual behaviour (p.30-31). Thus, ones' sustainable behaviour can be formed through education. This theory is very much inconformity with the UNESCO's definition on GCE.

With regard to Transformational Learning, the learner reflects on positive benefits of transformation. This engagement in turn, shows the theory of Reasoned Action at work in the life of an individual. Therefore, there is a subsisting relationship between the theory of reasoned action and transformational learning Tello (2013) et al: as cited in [32]. Accordingly, the theories of Reasoned Action, Active learning and Transformational Learning are interconnected and interrelated.

Table 7.1: Theoretical Perspectives of GCE

\begin{tabular}{|l|l|l|l|l|}
\hline Theory & Year & Scholar & Disclosure & Pedagogies \\
\hline Transformative & 1978 & $\begin{array}{l}\text { Jack } \\
\text { Meziro }\end{array}$ & $\begin{array}{l}\text { Habits and minds } \\
\text { influence our views and } \\
\text { interpretation }\end{array}$ & $\begin{array}{l}\text { Holistic approach; discussions, } \\
\text { Reflection, critical thinking, self-directed participatory, } \\
\text { integrated, interactive and engaging }\end{array}$ \\
\hline $\begin{array}{l}\text { Active } \\
\text { Learning(Constr } \\
\text { uctivism) }\end{array}$ & $\begin{array}{l}1896- \\
\text { Reasoned } \\
\text { Action }\end{array}$ & Jean Piaget & $\begin{array}{l}\text { Student centered learning } \\
\text { occurs in a contextual } \\
\text { setting }\end{array}$ & $\begin{array}{l}\text { Active learning in contextual setting, purposeful } \\
\text { participation, discussion, discussion ,project based } \\
\text { learning, autonomous and interactive learning }\end{array}$ \\
\hline
\end{tabular}

\subsection{Theoretical Perspectives of English Language Education (ELE)}

The theoretical foundation in terms of English as a second language acquisition would be provided by the combination of 4 models, namely; Comprehensible Input Hypothesis [33], Interactive Hypothesis [34], Comprehensible Output Hypothesis [35] and Experiential Learning Theory [36].

In regard to Krashan's Input Hypothesis (1982) plenty of language acquisition is enable when the students are highly motivated with high self-confidence but with low anxiety. Therefore, the students should be provided with adequate and comprehensible inputs. Not only the learner continuously use of second language, he should also receive the greater amount of inputs to use the language instantly [33]. In connection with Interactive Hypothesis proposed by Long (1983), second language acquisition takes place through interaction and its relationship to learners' understanding. This hypothesis propounds that we can make language more comprehensible by engaging more meaningful interactions. Next, related to Comprehensible Output Hypothesis by Swain (1985) [35] successful production of target language plays an important role in second language acquisition. This output would seem to have a potentially significant role in language learning.

With reference to the Experiential Learning Theory introduced by David Kolb (1984) [36] aims to integrate theoretical and practical elements with English Language Teaching (ELT) for a whole personal development. This approach employs rich variety of interactive practices whereby the participants have the opportunity to learn in an authentic setting and being actually involved in personalized learning. Thus, it involves the learner, makes him recalls, reflects, draws conclusions and prepares for actions but all throughout the process, teacher should provide necessary guidance, 
monitoring and feedback while giving a central role to learner participation. In that ELT gives prominent place to exposure and interaction.

In similar fashion, Yosof (2019) et al: [37] further indicate productive language learning occurs when there are proper awareness and commitments of the teachers in selecting appropriate materials, designing tasks with variety of strategies to ensure autonomous, authentic learning as well as reflective practices for integrated learning. This indication is inconformity with more recent study in which it says teachers' professionalism and attitude can greatly influence not only on language learners' achievement in target language but also to break communicative barriers and also to raise cultural awareness in them [38]. Moreover, this cultural diversity which we mostly experience in language classrooms today can indeed be an effective stimulus and motivational factor to enrich communicative component as well as to raise intercultural awareness in them [39]. Nonetheless, for effective language learning through practical integrated approach, syllabus designing should consider the existing conditions in the society. Because these current updated events can raise the learners' communicative skills [40]. Further, use of target language through task based interaction by providing appropriate content and also correct feedback enhance language learning.

Table 7.2: Theoretical Perspectives of Second Language Acquisition on (SLA)

\begin{tabular}{|l|l|l|l|l|}
\hline Theory & Year & Scholar & Disclosure & Pedagogies \\
\hline $\begin{array}{l}\text { Comprehensible } \\
\text { Input Hypothesis }\end{array}$ & 1981 & $\begin{array}{l}\text { Stephen } \\
\text { Krashan }\end{array}$ & $\begin{array}{l}\text { Acquisition through high } \\
\text { motivation, comprehensible input, } \\
\text { confidence but with low anxiety }\end{array}$ & $\begin{array}{l}\text { Discussion, } \\
\text { comprehension, } \\
\text { conversation, and self-reflection }\end{array}$ \\
\hline $\begin{array}{l}\text { Interactive } \\
\text { Hypothesis }\end{array}$ & 1983 & M.H.Long & $\begin{array}{l}\text { Acquisition through interactive } \\
\text { relationships and sufficient } \\
\text { comprehensive inputs }\end{array}$ & $\begin{array}{l}\text { Interaction, communication, } \\
\text { comersation, }\end{array}$ \\
\hline $\begin{array}{l}\text { Comprehensible } \\
\text { Output Hypothesis }\end{array}$ & 1985 & Merrill Swain & $\begin{array}{l}\text { Acquisition through } \\
\text { internalizing, reflection and } \\
\text { production }\end{array}$ & $\begin{array}{l}\text { Gap filling comprehension, } \\
\text { reflection, self-correction, role play }\end{array}$ \\
\hline $\begin{array}{l}\text { Experiential Learning } \\
\text { theory }\end{array}$ & 1984 & David Kolb & $\begin{array}{l}\text { Practical integrated approach, } \\
\text { interactive practices in authentic } \\
\text { settings, exposure monitoring and } \\
\text { effective feedback }\end{array}$ & $\begin{array}{l}\text { Experiential, transformational ,active } \\
\text { experiment, observation, } \\
\text { reviewing and reflection }\end{array}$ \\
\hline
\end{tabular}

When we scrutinize the application of this theory into ELE we can very well understand the befitting features of both elements. (Refer to table 1 and 2).Thus, these theoretical approaches in SLA and GCE as well as their pedagogical approaches are very much reciprocal and compatible. As illustrated in table 1 and 2 it is precisely clear both approaches suggest to have almost similar pedagogical techniques and contextual contents. In essence, in connection with all this theoretical support in research literature what is obvious is correlation and reciprocity of the two domains; GCE and ELE. Consequently, intermix of both disciplines can be implemented through well planned and welldesigned teacher education programmes with the help of effective teacher educators.

\section{Relationship between teacher education and English language education with Global Citizenship Education}

An extensive body of literature in research considers the significance of fostering teacher competence for sustainable implementation of GCE intending the wellbeing of the global community at large [4, 15, 18, 8, 41]. Particularly, since GCE is a complex and multi-dimensional process, teachers should be competent enough to disseminate it properly and thereby they are required to have additional preparation [12] However, designing and enactment of curriculum, to develop technologies and competences of teachers as well as teacher educators is a challenging enterprise [20]. It is a challenge at personal and at institutional level with ever growing future [42].Therefore, as Symeonidis (2018) suggests relevant educational stake holders, practitioners and in-service teachers have to focus on improving quality of profession. In that, instead of traditional top down dissemination process, the practitioners should be at the heart of knowledge creation process. Further, teachers being active agents of change should incorporate results of their education research work with every day practice.

As convinced by certain amount of literature, in connection with Global Citizenship Education and English Language Education, it is abundantly clear the corresponding nature of GCE and ELE [16, 41, 43, and 45]. With the 
globalization these two domains have been started to work as pull factors .Due to this reciprocal nature, English language has become limelight of the need of globalization. Therefore, it has forced people to learn English to sustain in this globalized world [46]. Thus, GCE and ELE walk side by side and therefore, globalization and spread of English are being intertwined. What is more important is communicative and practical use of English [44]. As they emphasize it is critical to use English to develop global citizenship. Therefore, without a doubt globalization has a fundamental impact on ELE. In fact, globalization is a catalyst to elevate ELE [47].Moreover, English is contributive to global uniformity. It is through English we realize our togetherness [45]. Pott's (2014) notion of living global citizenship emerges with the citizens actually engage in GCE work. Thereby, he stresses it is utmost important to strengthen ELE for actual global citizenship.

Table 8.1: Factors, contributing authors and research papers

\begin{tabular}{|c|c|c|}
\hline Varia & Authors/Years & s \\
\hline \multirow{6}{*}{$\begin{array}{l}\text { Global } \\
\text { Citizenship } \\
\text { Education }\end{array}$} & $\begin{array}{l}\text { Akkari \& Maleq } \\
\left(2019^{\prime}[4]\right.\end{array}$ & $\begin{array}{l}\text { Global Citizenship: Buzzword or New Instrument for Educational Change? } \\
\text { Europe's Journal of Psychology. }\end{array}$ \\
\hline & $\begin{array}{l}\text { Bourn } \\
\text { Hunt(2017)[5] }\end{array}$ & $\begin{array}{l}\text { A review of Education for Sustainable Development and Global Citizenship } \\
\text { Education in Teacher Education. Global Education Monitoring Report }\end{array}$ \\
\hline & $\begin{array}{l}\text { Bruce, North and } \\
\text { FitzPatrick [14] }\end{array}$ & $\begin{array}{l}\text { Pre-service teachers' views of global citizenship and implications for global } \\
\text { citizenship education. Globalization, Societies and Education, }\end{array}$ \\
\hline & $\begin{array}{l}\text { Buchanan, Burridge } \\
\text { and Chodkiewicz } \\
(2018)[15]\end{array}$ & $\begin{array}{l}\text { Maintaining Global Citizenship Education in Schools: A Challenge for } \\
\text { Australian Educators and Schools. Australian Journal of Teacher Education }\end{array}$ \\
\hline & Franch (2019) [18] & $\begin{array}{l}\text { Global Citizenship Education between Qualification, Socialization, and } \\
\text { Subjectification. The Palgrave Handbook of Citizenship and Education }\end{array}$ \\
\hline & $\begin{array}{l}\text { Yosof (2019) et al : } \\
\text { [17] }\end{array}$ & $\begin{array}{l}\text { Teachers' Perception of Students' Knowledge, Skills and Attitudes on Global } \\
\text { Citizenship. International Journal of Academic Research in Business and } \\
\text { Social Sciences. }\end{array}$ \\
\hline \multirow{6}{*}{$\begin{array}{l}\text { Teacher } \\
\text { Education }\end{array}$} & $\begin{array}{ll}\text { Kopish } & \text { and } \\
\text { Marques(2020) [19] }\end{array}$ & $\begin{array}{l}\text { Leveraging Technology to Promote Global Citizenship in Teacher Education } \\
\text { in the United States and Brazil. Research in Social Sciences and Technology }\end{array}$ \\
\hline & Banele (2019)[6] & $\begin{array}{l}\text { Factors for Teachers' Low Use of ICT in Secondary Schools in Tanzania. } \\
\text { International Journal of Research and Innovation in Social Science }\end{array}$ \\
\hline & (2018) [20] & $\begin{array}{l}\text { Introducing global citizenship education into classroom practice: a study on } \\
\text { Italian } 8^{\text {th }} \text { grade students. . Center for Educational Policy Studies Journal }\end{array}$ \\
\hline & $\begin{array}{l}\text { Abukhadrah (2016) } \\
\text { [48] }\end{array}$ & $\begin{array}{l}\text { The Role of Teacher Education Programmes in Creating Globally and } \\
\text { Internationally competent Teachers: An Annotated Bibliography. International } \\
\text { Journal of English Language Teaching. }\end{array}$ \\
\hline & (2020) [41] & $\begin{array}{l}\text { Teachers' perceptions of professionalism: a top down or a bottom-up } \\
\text { decision-making process? Professional Development in Education. }\end{array}$ \\
\hline & $\begin{array}{l}\text { Garcia and Weiss } \\
(2019)[7]\end{array}$ & $\begin{array}{l}\text { The role of early career supports, continuous professional development, and } \\
\text { learning communities in the teacher shortage Economic Policy Institute. }\end{array}$ \\
\hline \multirow{4}{*}{$\begin{array}{l}\text { GCE in } \\
\text { English } \\
\text { Language } \\
\text { Education }\end{array}$} & Porto (2019)[9] & $\begin{array}{l}\text { Affordances, complexities, and challenges of intercultural citizenship for } \\
\text { foreign language teachers. Foreign Language Annals. }\end{array}$ \\
\hline & Roux (2019)[16] & $\begin{array}{l}\text { Perspectives on Global Citizenship Education of Mexican University English } \\
\text { Language Teachers Global Education in Practice: Teaching, Researching, and } \\
\text { Citizenship. }\end{array}$ \\
\hline & $\operatorname{Diaz}(2017)[10]$ & $\begin{array}{l}\text { Citizenship Education and the EFL Standards: A Critical Reflection. Profile } \\
\text { Issues in Teachers' Professional Development, }\end{array}$ \\
\hline & $\begin{array}{lll}\text { Byram } & (2019) & \text { et } \\
\text { al:[11] } & & \end{array}$ & $\begin{array}{l}\text { Educating the Global Citizen International Perspectives on Foreign Language } \\
\text { Teaching in the Digital Age. Ludwig-Maximillian's-University .Munich }\end{array}$ \\
\hline
\end{tabular}

\section{CONCLUSION}

GCE has become an utmost important process in the sphere of education of the world today. This framing paradigm of learning domain consists of theory and practice of transformative education. Subsequently, it goes beyond cognitive 
domain of education to develop socio, cultural, behavioural and attitudinal competencies of learners. Thereupon, this core domain of education, facilitates and promotes the learners' social transformation while empowering them to be active and informed participants of bettering the world. Therefore, the presumption of this complex and multidimensional approach of GCE is to have efficient and skilful teachers of high calibre. In consequence, an enormous amount of studies in literature points out TE inarguably has a pivotal role in developing teachers' competences.

Paradoxically, as it convinces by plethora of literature in terms of GCE, teachers often encounter various challenges due to insufficient and ineffective theoretical and pedagogical practices. Therefore, despite of its uttermost necessity, unable to reach to the intended goals by the global community. To practice effective GCE ideals on a daily basis teachers' professionalism and active involvement are necessary. Hence, with regard to TE, teacher preparation and development should work as a continuum by providing a strong foundation with their initial TE and continuing with an effective in-service TE while enhancing their professionalism with continuous professional development programs. Nevertheless, plenty of literature witnesses complimentary nature of theoretical, pedagogical and contextual nature of GCE in ELE. However, this duel approach is an innovative but challenging one with less research area. Therefore, there is much scope yet to be explored in this field.

\section{REFERENCES}

[1] H. Aturupane, R. Ebenezer, H. Higashi, and S. Sosale, "Sri Lanka human capital development realizing the promise, and potential of human capital," Document of the World Bank,2019,pp. 72-108.

[2] A. K. Edward, and I. O. Mensah, "Challenges facing the effectiveness of secondary school teachers' continuous professional development in the Sekyere district: Enhancing practice with human performance technology," International Journal of Research, and Innovation in Social Science. 2019, Vol. 3, no. 48, pp. 391-403.

[3] S. Hin-Toh, G. Show, and D. Padilla, "Global citizenship education -A Guide for Policy Makers," (APCEIU) Press. Republic of Korea. 2017, pp. 10-39.

[4] A. Akkari, and K. Maleq, "Global citizenship: Buzzword or new instrument for educational change?" Europe's Journal of Psychology. 2019, vol. 15, no. 2, pp. 176-182.

[5] D. Bourn, and F. Hunt, "A review of education for sustainable development, and global citizenship education in teacher education," Global education monitoring report. 2017, pp. 6-50.

[6] D. S. Banele, "Factors for teachers' low use of ICT in secondary schools in Tanzania" International Journal of Research, and Innovation in Social Science. 2019, vol. 3, no. 3.

[7] E. Garcia, and E. Weiss, "The role of early career supports, continuous professional development, and learning communities in the teacher shortage,":The fifth report in 'The Perfect Storm in the Teacher Labor Market' series; Economic Policy Institute: Washington, DC, USA. 2019, pp. 1-32

[8] UNESCO, "Progress on education for sustainable development, and global citizenship education,” 2019.

[9] M. Porto, "Affordances, complexities, and challenges of intercultural citizenship for foreign language teachers," Foreign Language Annals. 2019, vol. 52, no. 1pp. 141-164.

[10] L. C. Diaz, "Citizenship education, and the EFL standards: A critical reflection. Profile Issues in Teachers' Professional Development,” 2017, vol. 19, no. 1, pp. 155-168.

[11]M. Byram,W. Gaudelli ,G. Hull ,L. Jackson ,C. Kramsch, G. Misiaszek, and H. Starkey, “ Educating the global citizen international perspectives on foreign language teaching in the digital age. Ludwig-Maximilians-Universität Munich. 2019, pp. 1-92.

[12] United Nations Office on Drugs, and Crime (UNODC), "Empowering students for just societies A handbook for secondary school teachers," UNESCO, France. 2019.

[13] E. Bosio, and C. A. Torres, "Global citizenship education: An educational theory of the common good? A conversation with Carlos Alberto Torres," Policy futures in education. 2019, vol. 17, no. 6, pp. 745-760. 
[14] J. Bruce, C. North, and J. Fitzpatrick, "Pre-service teachers' views of global citizenship, and implications for global citizenship education," Globalization, Societies, and Education. 2019, vol. 17, no. 2, pp. 161-176.

[15] J. Buchanan, N. Burridge, and A. Chodkiewicz, "Maintaining global citizenship education in schools: A challenge for Australian educators, and schools," Australian Journal of Teacher Education. 2018, vol. 43, no. 4, pp. 51-67.

[16] R. Roux, "Perspectives on global citizenship education of Mexican university English language teachers". Glocal education in practice, Teaching, researching, and citizenship. 2019, vol. 17, no. 1, pp. 139-145.

[17] H. Yusof, M. A. M. Noor, N. A. Jalil, M. Mansor, and J. Nordin, “Teachers' perception of students' knowledge, skills, and attitudes on global citizenship," International Journal of Academic Research in Business, and Social Sciences. 2019, vol. 9, no. 9, pp. 153-164.

[18] S. Franch, "Global citizenship education between qualification, socialization, and subjectification," The Palgrave handbook of citizenship, and education, 2019, pp. 1-16.

[19] M. A. Kopish, and W. Marques, "Leveraging technology to promote global citizenship in teacher education in the United States, and Brazil," Research in Social Sciences, and Technology, 2020vol. 5, no. 1, pp. 45-69.

[20] V. Damiani, "Introducing global citizenship education into classroom practice: a study on Italian $8^{\text {th }}$ grade students," Center for educational policy studies journal, 2018, vol. 8, no. 3, pp. 165-186.

[21] M. A. Kopish, "Global citizenship education, and the development of globally competent teacher candidates,"Journal of International Social Studies, 2017, vol. 7, no. 2, pp. 20-59.

[22] J. Hatley, "Universal values as a barrier to the effectiveness of global citizenship education: A multimodal critical discourse analysis," International journal of development education, and global learning, 2019, vol. 11, no. 1, pp. 87102.

[23] Oxfam, "Education for global citizenship, A guide for school in England: Oxfam education, and youth," Oxfam House, 2015, pp. 2-24.

[24] U. Sekaran, and R. Bougie, "Research methods for business: A skill building approach,” John Wiley \& Sons. Beekam print, New Delhi. 2016.

[25] J. Mezirow, "Transformative learning: Theory to practice. New directions for adult, and continuing education," 1997, vol. 74, pp. 5-12.

[26] M. Christie,M. Carey, A. Robertson, and P. Grainger, " Putting transformative learning theory into practice," Australian Journal of Adult Learning, 2015,vol. 55,no. 1: 9.

[27] C. Johanson, "An integrative model for transformative learning, Adult Education," Research Conference. 2008.

[28] S. Santalucia, and C. R. Johnson, "Transformative learning: Facilitating growth, and change through fieldwork," OT Practice, 2010, vol. 15, no. 19, pp. 1-7.

[29] M. Sullivan, and K. Pashby, "Citizenship education in the era of globalization: Canadian perspectives," Brock Education Journal, 2008, vol. 17, no. 1.

[30] M. Alanazi, "The acquisition of synonyms by Arabic-speaking EFL Learners: Evidence from University of Tabuk,"Doctoral dissertation, 2016.

[31] J. Lombardi, "What's so radical about radical constructivism?," $19^{\text {th }}$ International congress on personal construct psychology, 2011, pp. 1-5.

[32]E. S. Nwanchor, "Transformation towards sustainable living under global education approach: International students’ experience, “Doctoral Dissertation. Anglia Ruskin University, 2014.

[33] S. Krashen, "Principles, and practice in second language acquisition, Pergamon Press Inc. 1982.

[34]M. H. Long, "Native speaker/non-native speaker conversation in the second language classroom," University of Hawai'i working papers in English as a second language, 1983, vol. 2, no. 1. 
[35] M. Swain, "Communicative competence: Some roles of comprehensible input, and comprehensible output in its development, input in second language acquisition," 1985, vol. 15, pp. 165-179.

[36] D. A. Kolb, "The process of experiential learning. Experiential learning: experience as the source of learning, and development," Inc Prentice-Hall, 1984, pp. 20-38.

[37] A. T. Boggu, and J. Sundarasingh, "Language learning strategies among less proficient learners in Oman," Journal of Humanities, and Social Science, 2014, vol. 1, no. 9, pp. 46-53.

[38] S. A. Darwish "Teachers' attitude toward a foreign language: Factors affecting the target language teaching process," International Journal of English Language Teaching, 2017, vol. 5, no. 1.1

[39] A. U. Nwanyanwu, "Effective teaching of the English language in multicultural 12 Classrooms: the Nigerian perspective”, International Journal of English Language Teaching, 2017, vol. 5, no. 4, pp. 26-31.

[40] H. B. Bormanaki, and Y. Khoshhal, "The role of equilibration in Piaget's theory of cognitive development, and its implication for receptive skills: A theoretical study," Journal of Language Teaching, and Research. 2017, vol. 8, no. 5, pp. 996-1005.

[41] K. Ekanayake, M. Shukri, A. Khatibi, and F. Azam, "Global citizenship education practices, and teacher education," Journal of Education, society, and behavioral science. June 2020, vol. 33. pp. 36-47.

[42] V. Symeonidis, "Revisiting the European teacher education area: The transformation of teacher education policies, and practices in Europe," Center for Educational Policy Studies Journal, 2018, vol. 8, no. 3, pp. 13-28.

[43] F. Basarir, "Examining the perceptions of English instructors regarding the incorporation of global citizenship education into ELT," Global citizenship education, 2017, vol. 5, no. 4, pp. 409-425.

[44] S. Haidar, and F. Fang, "English language in education, and globalization: A comparative analysis of the role of English in Pakistan, and China," Asia Pacific Journal of Education, 2019, vol. 39, no. 2, pp. 165-176.

[45] M. Potts, "Living global citizenship: A new pedagogy for citizenship education," Educational Journal of Living Theories, 2014, vol. 7, no. 2, pp. 102-118.

[46] D. Crystal , "English as a Global Language ”( ${ }^{\text {nd }}$ Ed. $)$. New York: Cambridge University Press. 2012.

[47] I.C.Ke, "Globalization and global English: Panacea or poison for ELT in Taiwan?," Taiwan Journal of TESOL. 2010, vol.7, no.1, pp.1-27. 